OPEN ACCESS

Edited by:

Diane Cooper,

University of the Western Cape,

South Africa

Reviewed by:

Anuradha Rose,

Christian Medical College \& Hospital,

India

George J. Chang,

University of Texas MD

Anderson Cancer Center,

United States

*Correspondence:

Chhabi Lal Ranabhat

chhabir@gmail.com;

Chun-Bae Kim

kimcb@yonsei.ac.kr

Specialty section:

This article was submitted to Public Health Policy,

a section of the journal

Frontiers in Public Health

Received: 26 April 2017 Accepted: 01 September 2017 Published: 22 September 2017

Citation:

Ranabhat $C L$, Kim C-B, Singh DR and Park MB (2017) A Comparative

Study on Outcome of Government and Co-Operative CommunityBased Health Insurance in Nepal.

Front. Public Health 5:250.

doi: 10.3389/fpubh.2017.00250

\section{A Comparative Study on Outcome of Government and Co-Operative Community-Based Health Insurance in Nepal}

\author{
Chhabi Lal Ranabhat ${ }^{1,2,3 *}$, Chun-Bae Kim ${ }^{1,2 *}$, Dipendra Raman Singh ${ }^{4}$ \\ and Myung Bae Park ${ }^{5}$
}

${ }^{1}$ Department of Preventive Medicine, Yonsei University, Wonju College of Medicine, Wonju, South Korea, ${ }^{2}$ Institute for Poverty Alleviation and International Development, Yonsei University, Wonju, South Korea, ${ }^{3} \mathrm{Health}$ Science Foundations and Study Centre, Kathmandu, Nepal, " Ministry of Health, Public Health, Monitoring and Evaluation Division, Kathmandu, Nepal, ${ }^{5}$ Department of Gerontology, Health and Welfare, Pai Chai University, Daejeon, South Korea

Background: There are different models for community-based health insurance $(\mathrm{CBH})$, and in Nepal, among them, the government and the local communities (co-ops) are responsible for operating the $\mathrm{CBHI}$ models that are in practice.

Aims: The aim of this study is to compare the outcomes in relation to benefit packages, population coverage, inclusiveness, healthcare utilization, and promptness of treatment for the two types of $\mathrm{CBH}$ models in Nepal.

Methods: This study was an observational and interactive descriptive study using the concurrent mixed approach of data collection, framing, and compilation. Quantitative data were collected from records, and qualitative data were collected from key informants in all $12 \mathrm{CBHI}$ groups. Unstructured questionnaires, observation checklists, and memo notepads were used for data collection. Descriptive statistics and the Mann-Whitney $U$ test were used when appropriate. Ethically, written informed consent was obtained from the respondents who participated in the study, and they were told that they could withdraw from the study anytime.

Results: The study revealed the following: new enrolment did not increase in either group; however, the healthcare utilization rate did (Government 107\% and co-ops 137\%), while the benefit packages remained almost same for both groups. Overall, inclusiveness was higher for the government group. For the $\mathrm{CBHI}$ co-ops, enrollment among the religious minority and the discount negotiated with the hospitals for treatment were significantly higher, and the promptness in reaching a hospital was significantly faster $(p<0.05)$ than that in the government-operated $\mathrm{CBH}$.

Conclusion: Findings indicate that $\mathrm{CBH}$ through co-ops would be a better model because of its lower costs and ability to enhance self-responsiveness and the overall health system. Health insurance coverage is the most important component to achieve universal health coverage.

Keywords: community-based health insurance, co-operative, benefit package, social inclusion, healthcare, Nepal 


\section{INTRODUCTION}

Community-based health insurance (CBHI) is attracting attention in low- and middle-income countries as a means for improving healthcare utilization and protecting households against impoverishment caused by out-of-pocket medical expenditures. The World Health Organization and the World Bank have continuously suggested reducing out-of-pocket payments (OPPs) and promoting universal health coverage (UHC) $(1,2)$. Different health financing approaches have been developed to counter the detrimental effects of user fees introduced in the 1980s, but those efforts have not yet increased healthcare utilization, particularly among marginalized populations and, moreover, sometimes lead to catastrophic health expenditures (CHEs) (2-4). There are different models of health insurance; among them, $\mathrm{CBHI}$ is the most widely used among middle-income populations and in remote areas. CBHI has been implemented on a small scale in Nepal, but its effectiveness remains a critical question.

There are different models of health insurance. Mandatory and single payer health insurance models are considered to be among the better approaches, but it is very difficult to collect premiums in low- and middle-income countries due to a profound dearth of economic activities in the informal sector and a lack of information technology that is compatible with premiums (5). Likewise, for people who are ultra-poor and live in rural areas, enrolling in health insurance is an additional challenge. The government-only approach is unable to provide universal health insurance because the primary responsibility for health falls upon each individual. In the United States, the Obama administration proposed reducing healthcare costs and providing affordable health service using a co-operative concept (6); and co-operative health insurance is also replacing private health insurance in Canada (7). Voluntary health insurance could be a step forward to lower risks associated with illness.

There are two approaches to voluntary health insurance that have been initiated by both the government and local communities. Some studies have investigated the outcomes of CBHI in low- and middle-income countries, but their results have been inconsistent. Several previous reviews have evaluated the performance of $\mathrm{CBHI}$ in terms of enrollment, financial management, and sustainability $(8-10)$. One study from Laos indicated that the government-funded CBHI has low coverage, but the insured people have a significantly higher level of healthcare utilization, lower OPPs, lower incidence of catastrophic expenditures, and a lower propensity to employ coping mechanisms (11). In a study in Ethiopia, out-patient department (OPD) services increased, while inpatient department (IPD) services remained the same even after the implementation of CBHI (12). However, people were not convinced that they should enroll in CBHI, and the coverage rate was thereby unsatisfactory.

There are some successful reports of voluntary health insurance through community initiatives, such as in Vietnam (13) and Japan (14), and government initiatives in some developing countries. In China, a New Co-operative Medical Scheme (NCMS) was piloted, and it had mixed results (15). Similarly, the state government of Karnataka in India also made health insurance available to its people and tried to reduce OPPs and CHE
(16). Previous studies have largely focused on the single model of CBHI, and comparison of outcomes between government and co-operative CBHI models is rare globally, and none has focused on Nepal.

Over the past two decades, the government of Nepal has spent less than $5 \%$ of the total budget on health care, while more than two thirds of the population used OPPs during illness (17) and over 13\% had CHEs due to vehicular injuries, diabetes, asthma, and/or heart disease $(18,19)$. In Nepal, more than $80 \%$ people live in villages, and the livelihood of $75 \%$ of these people is subsistence agriculture; hence, they cannot purchase any medical care, and to date, health insurance has covered only less than $5 \%$ of total population (20). For example, in the case of child pneumonia, the direct cost for treatment per case was $\$ 25$, and its indirect cost was $\$ 312$, indicating that there is a great loss when there is illness in a family (21). Until now, more than one-fourth of the population has used endogenous and complementary and alternative therapy (22). Obviously, the government does not have sufficient funds to finance all health expenditure for the entire population.

Lack of sustainable health financing has resulted in highly unequal health care, and such inequalities affect both rich and poor, urban and rural, male and female, and upper caste and disadvantaged groups. In Nepal, there have been several experiments with CBHI reported since 2004 in both rural and urban settings (23). Provider-based health insurance was introduced in Nepal in 2003 through six pilot schemes offered by the government. At the same time, some community groups (co-ops) started CBHI on their own initiative supported by non-governmental organizations (NGOs) (24). CBHI schemes in Nepal complemented a number of specialized programs to improve access to healthcare services.

The aim of this study is to compare the outcomes of CBHIs in Nepal, both CBHIs offered by government health facilities and those offered by community groups, in terms of benefit packages, population coverage, inclusiveness, healthcare utilization, and promptness of treatment.

\section{MATERIALS AND METHODS}

\section{Study Design}

This study was an observational and interactive descriptive study composed of qualitative and quantitative data sources.

\section{Methods of Study}

After crystallizing the research outcomes, a study team was established. The study area, tools, respondents, data collection methods, data analysis, and synthesizing approach were finalized. Study team included all authors, statisticians, field supervisors, and community rapport builders. We used a combined descriptive research method, which consisted of quick observations and interactive methods with respondents for higher reliability and an applicable approach in which each part complemented the other in the operational research $(25,26)$.

\section{Study Approaches}

A mixed method approach would be appropriate for both qualitative and quantitative data comparisons between two groups 
and for synthesizing the results (27). We used Driscoll et al.s concurrent structure survey by applying open-ended and closedended questions with the same respondents (28) (Figure 1). This method integrates research questions, employs rigorous quantitative research assessing magnitude, and explores the meaning and understanding of concepts; it utilizes multiple processes, combines these to draw on their strengths, and frames the investigation within philosophical and theoretical positions (29). Recently, Creswell (30) emphasized that such an approach is better for philosophical, theoretical, and methodological perspectives. Qualitative research seeks to understand how individuals explore and perceive their experiences. Quantitative research is more powerful for generalization of the findings, whereas a combined approach is more valid, reliable, and replicable. Thus, the mixed impact of both designs is more powerful than a single approach.

\section{Study Sampling and Characteristics of Respondents}

We used all (not selected) volunteer-based health insurance groups, both government-operated CBHI (6) and co-operative groups CBHI (6). Both types of CBHIs are demonstration projects regulated by the Ministry of Health $(\mathrm{MoH})$, Nepal. Other characteristics are discussed below (Table 1).

\section{Study Setting}

Being a concurrent mixed study, we obtained data from institution and opinions from key informants. The institutions were selected purposively, and totally 12 institutions were included, of which 6 were government health centers and 6 were co-ops conducting CBHI. The qualitative information was collected from the responsible (focal) person in each government health center and the member secretary of co-ops and chairperson of health center and co-operative group. Their responses were categorized and presented in a narrative form after the data results and summary statements were presented by each group.

\section{Study Group and Population}

We selected two models of CBHI in Nepal.

\section{Government-Run, CBHI (Group A)}

This group had six pilot areas, governed by the $\mathrm{MoH}$ of Nepal, based on a population survey done more than 5 years before. Primary health centers and district-level hospitals offered benefit packages of health insurance using their own management. They operated on government financing.

\section{Co-Operative Prepayment Health Organization (Group B)}

This group had six community groups governed by these communities in collaboration with private and government hospitals. This model can be defined as a zero-cost financing model that empowers these community groups. There was some support from NGOs, but this was only in-kind support. Funding came from their regular savings, subsidies, and donations from other

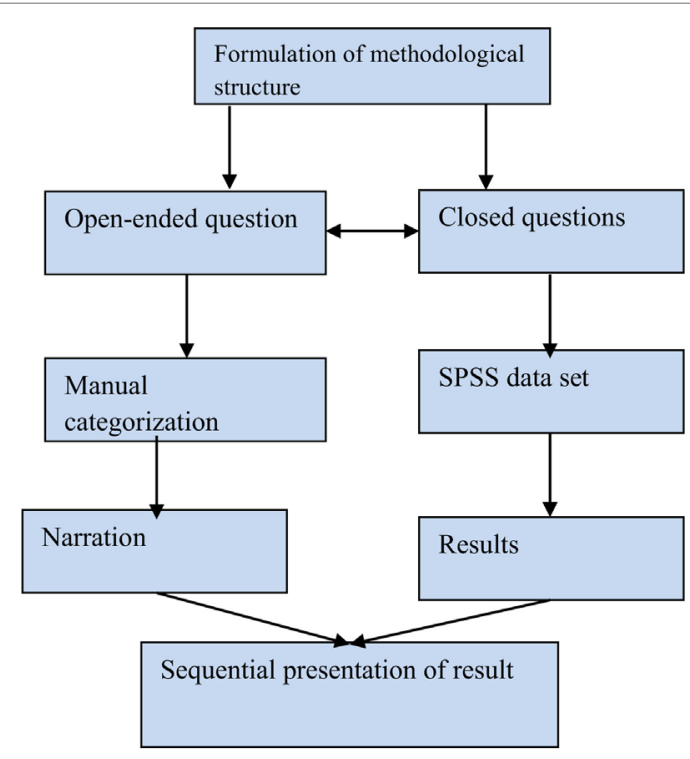

FIGURE 1 | Concurrent mix study design: Driscoll (28).

TABLE 1 | Characteristics of data and respondents.

\begin{tabular}{|c|c|c|c|}
\hline \multicolumn{2}{|l|}{ Characteristics } & $\begin{array}{l}\text { Government } \\
\text { community-based } \\
\text { health insurance } \\
\text { (CBHI) }\end{array}$ & Co-ops CBHI \\
\hline \multicolumn{2}{|c|}{ Quantitative data approach } & $\begin{array}{l}\text { From the record } \\
\text { registers }\end{array}$ & $\begin{array}{l}\text { From the record } \\
\text { registers }\end{array}$ \\
\hline \multirow[t]{3}{*}{$\begin{array}{l}\text { Qualitative data } \\
\text { approach }\end{array}$} & $\begin{array}{l}\text { No. of key } \\
\text { informants }\end{array}$ & $\begin{array}{l}\text { Two for each } \mathrm{CBHI} \text { : } \\
\text { chairperson and focal } \\
\text { person (12) }\end{array}$ & $\begin{array}{l}\text { Two for each } \mathrm{CBHI} \text {; } \\
\text { member secretary and } \\
\text { chairperson (12) }\end{array}$ \\
\hline & $\begin{array}{l}\text { Key informant } \\
\text { guidelines }\end{array}$ & Used and similar & Used and similar \\
\hline & Recorder & Used & Used \\
\hline \multicolumn{2}{|l|}{$\begin{array}{l}\text { Involvement of } \\
\text { stakeholders }\end{array}$} & No & No \\
\hline
\end{tabular}

organizations, and some amount of benefits came from group income generation activities.

\section{Study Area}

The study areas were obtained from all 12 pilot organizations that had managed government health facilities and co-operative organizations (Table 2). The geographical region of community groups and government $\mathrm{CBHI}$ is presented in the map (Figure 2).

\section{Study Tools and Technique}

Three sets of study tools were prepared for information collection.

\section{Review of the Records for Quantitative Data through Observation}

Data were obtained from the logbooks, ledgers, enrollment registers, and meeting minutes of the health facilities and cooperative groups. From these, the characteristics and coverage 
levels of the enrollees were determined. The characteristics gathered included age, gender, religion, and ethnicity of enrollees. The following information was collected from the records of each group:

1. Did you have any targets for new enrollment in the past year?

1.1. If yes, did you have a special scheme for new enrollments?

2. What was the amount of the benefit packages you provided to the enrollee?

3. From your $\mathrm{CBHI}$, what population is covered?

TABLE 2 | Community-based health insurance (CBHI) operated by government and community groups.

\begin{tabular}{|c|c|c|}
\hline S.N. & $\begin{array}{l}\text { CBHI conducted by government } \\
\text { (established year) }\end{array}$ & $\begin{array}{l}\text { CBHI conducted by community } \\
\text { groups (established year) }\end{array}$ \\
\hline 1 & $\begin{array}{l}\text { Lamahi Primary Health Care } \\
\text { Centre (2006) }\end{array}$ & $\begin{array}{l}\text { Madhesa health post management } \\
\text { committee (2010) }\end{array}$ \\
\hline 2 & Tikapur Hospital (2006) & Syaphru (2009) \\
\hline 3 & $\begin{array}{l}\text { Mangalabare Primary Health } \\
\text { Care Centre (2004) }\end{array}$ & Rajmarga (2003) \\
\hline 4 & $\begin{array}{l}\text { Dumkauli Primary Health Care } \\
\text { Centre (2004) }\end{array}$ & Bikalpa (2001) \\
\hline 5 & $\begin{array}{l}\text { Chandranigahapur Primary } \\
\text { Health Care Centre (2006) }\end{array}$ & $\begin{array}{l}\text { Primary Health Care and Resource } \\
\text { Center (PHCRC), Chapagaun } \\
(1972)\end{array}$ \\
\hline 6 & Katari Hospital (2006) & Saubhagya (2011) \\
\hline
\end{tabular}

4. What is the composition of your enrollees (minorities, disadvantaged groups, poor, etc.) in relation to social inclusion?

5. What is the utilization rate of public health services among CBHI members?

6. Do you have any official contracts with health service providers (government and private hospitals)?

6.1. If yes, what kinds of agreements do you have (annually, biannually, etc.)?

7. Do you negotiate with health service providers within their standard price of treatment?

7.1. If yes, how much (Rupee or percentage)?

8. Do you have your own ambulance service to use during emergencies?

\section{Key Informant Interview Guidelines for Qualitative Outcomes}

The key informant interview guidelines were used to assess management's experience with $\mathrm{CBHI}$ groups. The informants were the focal person of government health institution and the member secretary of co-ops interviewed in the presence of the chairperson in an interactive way. The key informant's voice was recorded on a mobile phone, and the essence was presented as results. In particular, the problems and challenges were obtained from the key informant interview process.

1. When did you initiate the CBHI?

2. What problems and challenges does your CBHI face in relation to new enrollments, dropouts, reliability, and satisfaction?

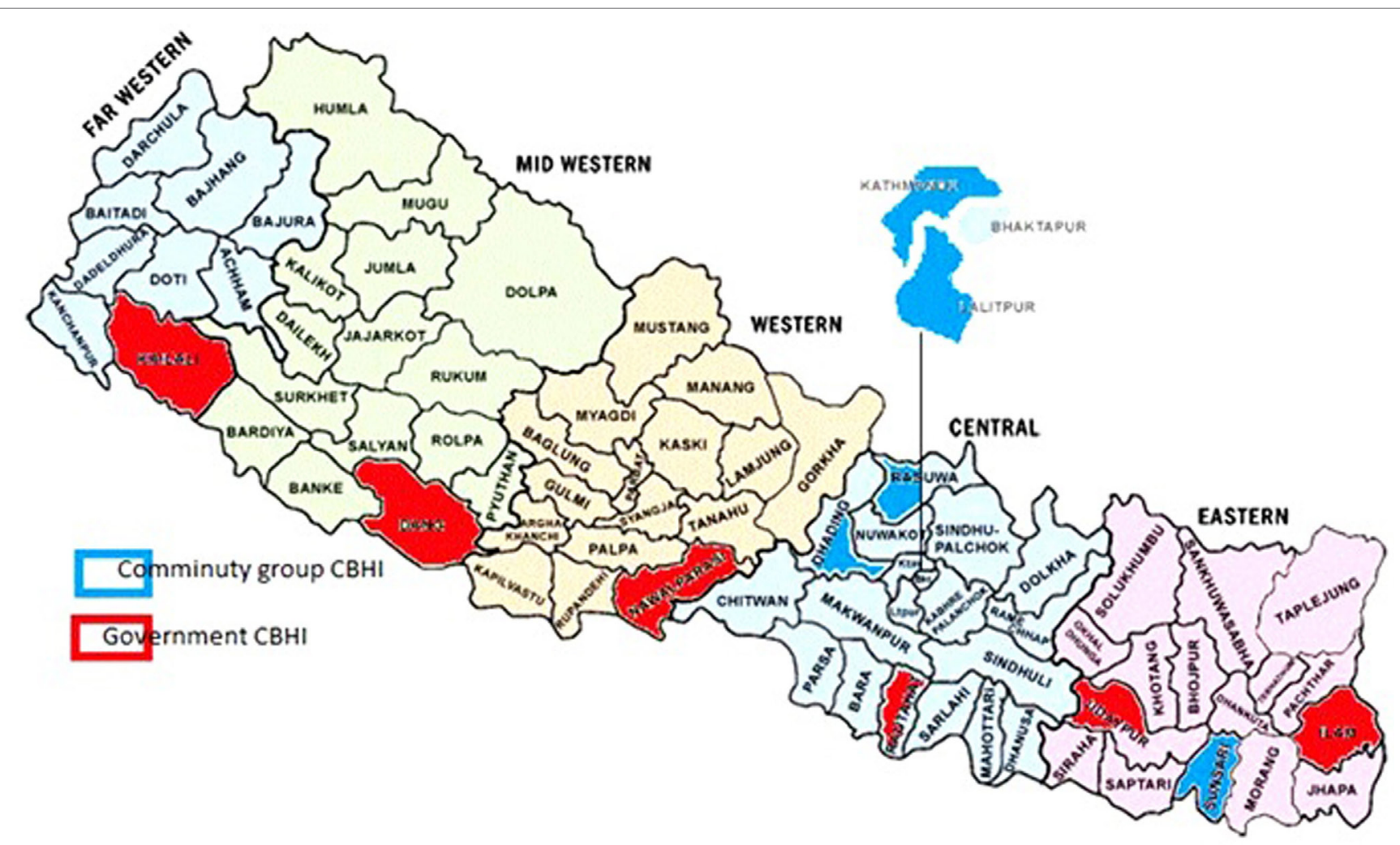

FIGURE 2 | Geographical location of community-based health insurance. 
3. Who supports your group, and what kind of support do they provide?

4. What suggestions do you have for the government and any supporting organizations?

5. How do you sustain the program in terms of governance and financial support?

\section{Observation Checklist}

The observation checklist was prepared to identify the physical infrastructure, office setting, recording and reporting status, membership cards, registration, patient records, and bank ledgers and to observe income-generating activities. Informal questionanswer sessions, individual relationships, and breakfast and break time were utilized as techniques.

\section{Data Management}

The data were divided into two parts. The numeric data were exported into Excel and analyzed using the Statistical Package for the Social Sciences (SPSS) version 22. Likewise, the qualitative information was categorized into different groups. Common information was presented in a narrative form.

\section{Data Analysis}

In the first phase, the descriptive findings were plotted based on different categories related to enrollment, population coverage, and population composition. In the second phase, numeric data were analyzed and tested statistically by applying the Mann-Whitney $U$ test as a two-group comparison. Finally, the data and qualitative information were matched and presented simultaneously.

\section{Research Outcome Analysis}

This was a group-based study, and the main outcome was presented by comparing two group's mean as below:

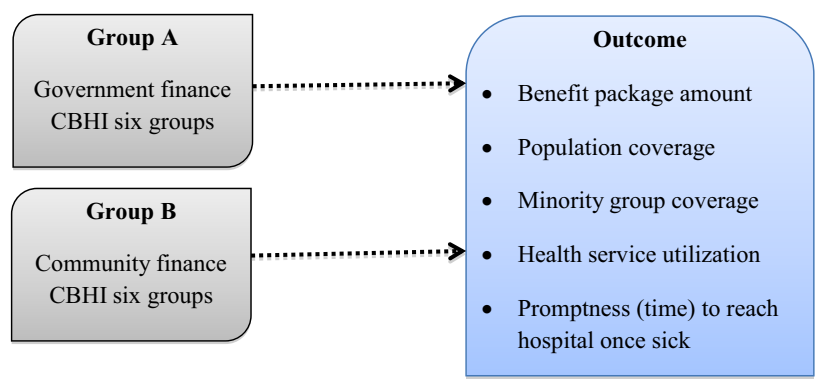

\section{Validity and Reliability}

The results were synthesized carefully according to the data synthesis model for both qualitative and quantitative information. Numeric data were repeatedly checked by the appointed researcher and were cross-verified by another researcher. The tools were pretested in a similar community using video recordings. Necessary changes were made to the tools after the pilot study. The mixed method of descriptive study produces a high power of communicative validity, expert validity, argumentative validity, and cumulative validity compared to other methods (31).

\section{Ethical Consideration}

Study approval was granted by the Department of Health Service (DoHS) of Teku, Kathmandu, Nepal, and a formal letter was sent to the co-operatives and government health facilities. The research was done according to international research ethical guidelines and Nepal health research council ethical guidelines (32). The respondents were clearly informed that the interviews were part of a research project and their responses might be part of a publication. Informed consent was obtained from respondents (focal person, member secretary, and chairperson of all CBHI) in accordance to the declaration of Helsinki so that it was a volunteer participation, and the information provided by respondents were confidential and it would not be used for any other purpose and respondents could withdraw their participation at anytime (33).

\section{RESULTS}

In this study, a comparison of the outcomes of the government and the co-operative health insurance plans in Nepal was performed. In the government CBHI, 4,364 households with 22,691 individuals were enrolled, and in the co-ops, 2,152 households with 10,106 individuals were enrolled, showing that the average family size was higher (5.2 person) in government group than that in the co-ops (4.3 person). The composition of men and women was almost equal; the adult population was dominant, and most people were of the Hindu religion and there was mixed ethnicity. Enrollment was not satisfactory (low), and population coverage was minimal. The demographic features were not much different during the piloting of the projects. The benefit package was slightly higher for the co-op group, while population coverage was better for the government group. Inclusiveness, overall management, and proxy activities were better in the co-op group (Table 3).

\section{Result from Qualitative Information Taken by Key Informants Interview}

Qualitative information was collected from 24 participants. Among them, 12 (50\%) were presidents of health centers and co-ops having intermediate education and 12 (50\%) of the member secretaries were graduated from university. Eight $(33.33 \%)$ participants were female and five were from disadvantage groups. Age of the respondents was 20-48 years.

A similar result was found during the key informant interviews. Both representatives reported that there was less interest in new enrollment. During the observations and conversations with key informants, the following results were found.

\section{Government-Operated CBHI}

Although many people receive services from the government health facilities, the services that are generally provided are not promoted with insured patients to promote health insurance. There are similar types of problems and challenges for the government-operated CBHI. According to key informants' information, people were not interested in $\mathrm{CBHI}$ because enrollment in $\mathrm{CBHI}$ did not result in their getting significant quality health 
TABLE 3 | Descriptive comparison between government and community groups community-based health insurance $(\mathrm{CBHI})$.

\begin{tabular}{|c|c|c|c|}
\hline \multicolumn{2}{|l|}{ Indicators } & Government & Co-operative \\
\hline \multicolumn{4}{|c|}{ ENROLLMENT AND BENEFIT PACKAGE } \\
\hline \multicolumn{2}{|c|}{ Enrollment target } & Not achieved & No fix target \\
\hline \multicolumn{2}{|l|}{ Scheme } & $\begin{array}{l}\text { No special subsidy } \\
\text { beyond the benefit } \\
\text { package }\end{array}$ & $\begin{array}{l}\text { Some discounts for those } \\
\text { who want to enroll in } \\
\text { groups and those with a } \\
\text { poor economic status }\end{array}$ \\
\hline \multicolumn{2}{|c|}{$\begin{array}{l}\text { Benefit package in Nepali } \\
\text { rupees }\end{array}$} & $\begin{array}{l}\text { Medicines, diagnostic } \\
\text { services, hospitalization, } \\
\text { and transportation } \\
\text { (Rs 6,000-20,000) }\end{array}$ & $\begin{array}{l}\text { Medicines, diagnostic } \\
\text { services, hospitalization, } \\
\text { and transportation } \\
\text { (Rs 6,000-29,000) }\end{array}$ \\
\hline \multirow[t]{2}{*}{$\begin{array}{l}\text { Enrollment } \\
\text { coverage (\%) }\end{array}$} & $\begin{array}{l}\text { New } \\
\text { members }\end{array}$ & $3.4 \%$ & $2.4 \%$ \\
\hline & Renewal & $\begin{array}{l}\text { Negative trend up } \\
\text { to } 47 \%\end{array}$ & Constant \\
\hline \multicolumn{2}{|c|}{$\begin{array}{l}\text { Membership coverage in } \\
\text { the catchment area (\%) }\end{array}$} & 53 & 26 \\
\hline \multicolumn{4}{|c|}{ ENROLLMENT COMPOSITION } \\
\hline \multicolumn{2}{|c|}{ Religious minority (\%) } & 3 & 36 \\
\hline \multicolumn{2}{|c|}{ Disadvantaged Terai (\%) } & 2 & 3 \\
\hline \multicolumn{2}{|c|}{$\begin{array}{l}\text { Utilization of health } \\
\text { services (\%) }\end{array}$} & $107(42-162)$ & $137(6-230)$ \\
\hline \multicolumn{2}{|c|}{$\begin{array}{l}\text { Receiving a discount } \\
\text { after negotiation (\%) }\end{array}$} & 19 & 40 \\
\hline \multicolumn{2}{|c|}{ Scheme viability } & Less viable & Average \\
\hline \multicolumn{2}{|c|}{ Legal framework } & $\begin{array}{l}\text { No legal framework in } \\
\text { the } \mathrm{MoH}\end{array}$ & $\begin{array}{l}\text { Legalized under } \\
\text { co-operative law }\end{array}$ \\
\hline \multicolumn{4}{|c|}{ MANAGEMENT } \\
\hline \multicolumn{2}{|l|}{ Audit system } & Rarely audited & Regularly audited \\
\hline \multicolumn{2}{|l|}{ Software } & Not in practice & Computer recording \\
\hline \multicolumn{2}{|c|}{$\begin{array}{l}\text { Human resources for } \\
\text { health insurance }\end{array}$} & $\begin{array}{l}\text { Paramedic of hospital as } \\
\text { focal person }\end{array}$ & Secretary of co-ops \\
\hline \multicolumn{2}{|c|}{$\begin{array}{l}\text { Relationship with } \\
\text { providers }\end{array}$} & $\begin{array}{l}\text { No contract with } \\
\text { providers }\end{array}$ & $\begin{array}{l}\text { Two co-operatives have } \\
\text { contracts with providers } \\
\text { at district and regional } \\
\text { hospitals }\end{array}$ \\
\hline \multicolumn{2}{|l|}{ Referral service } & $\begin{array}{l}\text { Referred by ambulance } \\
\text { or public vehicle to their } \\
\text { own health center }\end{array}$ & $\begin{array}{l}\text { All of them have their own } \\
\text { ambulance }\end{array}$ \\
\hline \multicolumn{2}{|l|}{ Subsidy } & From the government & None \\
\hline \multicolumn{2}{|l|}{ Sustainability } & $\begin{array}{l}\text { Depends on government } \\
\text { funding }\end{array}$ & $\begin{array}{l}\text { Have their own funds, but } \\
\text { not sufficient }\end{array}$ \\
\hline \multicolumn{4}{|c|}{ PROXY INDICATORS } \\
\hline \multicolumn{2}{|c|}{$\begin{array}{l}\text { Income generation } \\
\text { activities }\end{array}$} & No & $\begin{aligned} & \text { Yes } \\
& \text { Co-operative vegetable } \\
& \text { farming } \\
&>\text { Poultry farming } \\
& \Rightarrow \text { Small livestock }\end{aligned}$ \\
\hline
\end{tabular}

service, in comparison with people not enrolled. The people who enrolled in CBHI ignored continuing membership because enrolled people who were not sick did not get any benefit from the CBHI package and felt the loss of money. On the other hand, the subsidy provided by the local government was for ultra-poor and for a limited time only. As a result, there was a high dropout
TABLE 4 | Comparison of health indicators between the two CBHI models.

\begin{tabular}{llcc}
\hline Variables & $\begin{array}{l}\text { Type of } \\
\text { organization }\end{array}$ & Mean \pm SD & p-Value \\
\hline Amount of benefit package in & $\begin{array}{l}\text { Government } \\
\text { Co-operative }\end{array}$ & $\begin{array}{c}14,333 \pm 6,775 \pm 43,184 \\
\text { Rupees }\end{array}$ & 0.108 \\
\hline Coverage population per group or & Government & $3,781 \pm 1,945$ & 0.057 \\
health center & Co-operative & $1,684 \pm 1,390$ & \\
\hline Coverage of overall inclusiveness in & Government & $1,930 \pm 1,120$ & 0.010 \\
numbers per group or health center & Co-operative & $417 \pm 362$ & \\
\hline Inclusiveness of religious minorities & Government & $78 \pm 56$ & 0.048 \\
(numbers) & Co-operative & $547 \pm 523$ & \\
\hline Inclusiveness of disadvantaged & Government & $64 \pm 100$ & 0.940 \\
Terai (\%) & Co-operative & $70 \pm 168$ & \\
\hline Health service utilization rate (\%) & Government & $107 \pm 43$ & 0.524 \\
\hline Proportion of discounts after & Go-operative & $137 \pm 102$ & \\
negotiation (\%) & Co-operative & $40 \pm 7$ & 0.003 \\
\hline $\begin{array}{l}\text { Average response for treatment } \\
\text { after illness/injury (initial and refer) to }\end{array}$ & Government & $118 \pm 38$ & 0.008 \\
reach hospital (min) & Co-operative & $38 \pm 45$ & \\
\hline
\end{tabular}

rate. For the volunteer model of health insurance, availability of a pharmacy operated by hospital workers on hospital premises is a main challenge for the future of CBHI. Health workers and other personnel lacked experience in health insurance management and realized that they could not provide priority to insured patients or encourage new enrollment because the staff already had high workloads. The allocated budget was not recorded properly and used for administrative purposes (traveling and daily allowance).

\section{Co-Ops Operated CBHI}

Community groups had different experiences. Some NGOs supported capacity building for health workers, such as training, workshops, and materials. They had a better networking and bonds with $\mathrm{CBHI}$ users and financial transparency, but service quality was no different than the government-operated CBHI. Involvement of all types of members in CBHI, government ignorance to guide and provide subsidy to co-ops CHBI, volunteer type of insurance models, and inability to increase the hospital service quality were the main challenges for co-ops CBHI. These co-op groups properly maintained records compared with the government health facilities, but the recording systems were not consistent. All co-ops reported that they provided awareness on sustainable health financing, and as a result, they had few dropouts. They just started to use computer-based records for each patient, expenditures, and other important decisions. They had collected more funds from their members and minimized administrative costs. Due to their strong negotiating skills, they had saved some money during service contracts with hospitals and invested this amount for other income-generating activities. There was quite a different conversation with the representative member from the co-ops.

Table 4 shows a comparison of the mean of each group variable examined in numeric data. The proportion of overall inclusiveness for the government group was significantly higher $(p<0.05)$ than that of the co-op group. However, the amount of negotiation 
and average response for treatment after illness/injury (initial and refer) were significantly better for the co-op group compared to that of the government health facilities.

The results from the qualitative and quantitative methods clearly show the effectiveness of government-operated and coops-operated CBHI in Nepal. Each finding complements the other.

\section{DISCUSSION}

The characteristics of the two models of CBHI in Nepal are clearly shown in this study. The population coverage was significantly higher in the government-conducted $\mathrm{CBHI}$, but inclusiveness and institutional capacity were stronger in the co-ops. Health insurance has been in operation in Nepal for a long time on a small scale, but the Ministry of Health $(\mathrm{MoH})$ has been unable to establish milestone targets for UHC. Existing government $\mathrm{CBHI}$ programs are not attractive to people and the co-op CBHI has poor coverage as well, but they have a positive direction. User fees, community drug programs, and free health service policies in the past have created confusion among individuals looking to enroll in $\mathrm{CBHI}$ (34). We found comparatively large coverage and relatively flexible premiums (in terms of payment schedules) and subsidies for the ultra-poor in the governmentrun CBHI. However, in this model, the local communities were unable to take ownership, and there was very low utilization of the resources. By contrast, in the co-ops, prepayment $\mathrm{CBHI}$ engendered trust and a feeling of ownership. A similar conclusion was drawn by Mebratie et al. (35) in a systematic review published in 2013.

In looking at our results and comparing these with other studies, we found similar trends. Enrollment is the first step in any CBHI model. Based on the large number of enrollees, the average enrollment was significantly higher in the government CBHI model, but the number of disadvantaged minorities was significantly higher in the co-op group. This finding is similar to results in a study in India that women in self-help groups found more inclusiveness among minority populations (36). In both groups, healthcare utilization increased significantly (up to two times), and this condition was also observed in the Sky Community Group in Cambodia (37); the Grameen Bank group in Bangladesh (38); the Government Amhims group in Ghana (39); Jaminan Kesehatan Aceh (JKA) scheme in Indonesia (40); and the Mutelleus Government Centre in Rwanda (41), Kerala (India) (42), and Vietnam (43). At the same time, coverage of the population in the catchment area was low in both groups. The same trend was observed in the People's Democratic Republic of Laos (11). New enrollment and retention of current enrollees was low in both models due to uncertain financial viability, quality of care, long waiting time when seeking care, and the poor management skills of healthcare providers that was found in Ghana too (44). Yeshavani is a co-operative CBHI provider in India (45), and Urban Resident Basic Medical Insurance (URBMI) has the same function in China (46) similar to the government CBHI model in Nepal. In both cases, people from remote areas and those in the higher education class were not interested in enrollment, similar to a trend in Mali (47), and findings are similar to our results. The number of new enrollees has been decreasing in the Hanang district of Tanzania (48), as in the government CBHI in our study. Enrollment of members of the Terai disadvantaged group was significantly higher in the co-op insured group; this finding is similar to the results from the SEWA group in India (49), but the Nouna community health organization in Burkina Faso (50) and the Mutual Health Organizations in Senegal (51) have not been able to cover disadvantaged groups.

The discounts provided during service contracting with hospitals were significantly larger $(p<0.05)$ for the co-op group (by effective negotiation skills) versus the government CBHI. This is not only beneficial for the sustainability of the health insurance industry but also empowers individual and institutional capabilities.

In India, it was concluded that people's negotiating power reduced the costs and improved the quality of service (52). In Canada, per-patient cost was $17 \%$ lower than the average price; hospitalization rates were up to $30 \%$ lower, and $21 \%$ less money was spent on prescription drugs (53) in co-operative health insurance compared to private health insurance. In China, the operating capacity of a CBHI is significantly higher in a new NCMS than it is in a government health insurance scheme (54). In addition, health service quality and profit-generating activities were launched in co-operative health insurance in Canada (55). In a Nigerian co-operative model, awareness of sustainable health financing through counseling was better, and there is a low dropout of enrollee (56). The above results from India, Canada, Nigeria, and China were similar to our findings.

The health insurance industry in Nepal has been in existence for a long time, but coverage is still low, and there are only a few successful CBHI models. The health insurance plans offered by co-operative groups are a newly growing strategic movement in health service in the country. With proper subsidies from the government and long-term contracts with advanced hospitals, health insurance offered by community groups could be more effective as an almost zero cost financing model, and health equity and quality of service in Nepal could be more accessible to people. However, as a whole, CBHI has achieved limited success in terms of community participation, self-health care, and social unity. Thus, significant support such as enough training, awareness increasing in the community, and performance-based subsidies are still necessary for both CBHI models as shown in the case of East Africa (57). There are different minority groups in $\mathrm{Nepal}$ and inconsistency region by region. So, overall inclusiveness of religious minorities and the disadvantaged Terai group is not in equal proportion to government-operated and co-operative groups in this study. There are some limitations in our study. There were no sufficient variables to compare co-operative and government health insurance. The results of this study are from the supply side (government health facilities and community groups), and findings may differ when the demand side (consumers/user) is examined. The interpretation of results needs treated with care generalization. In addition, some information from the key people interviewed may be more subjective, and there is a risk in generalization. 


\section{CONCLUSION}

Community health insurance programs have multiple and longterm impacts because they can reduce financial pressure on the government and would be responsible for maintaining health and empowering people. More importantly, it is necessary to reduce the out-of-pocket expenditures and CHEs (58) for newly designated community groups in developing countries, especially those in remote areas and for people in urban areas who cannot afford private health care. Government should provide subsidies based on the performance for both groups, and NGO should have supporting role such as training and logistic support. Ultimately, successful CBHI models could be a milestone to achieve Universal Health Coverage.

\section{AUTHOR CONTRIBUTIONS}

CR took overall responsibility for manuscript publication, from concept formation, study design, information collection data management, manuscript preparation, compilation of comments, and feedback to manuscript submission. C-BK monitored and

\section{REFERENCES}

1. World Health Organization. Health Systems Financing: The Path to Universal Coverage. Geneva: WHO (2010).

2. Hsiao W, Shaw R, Fraker A, Hanvoravongchai P, Jowett M, Pinto D, et al. Social Health Insurance for Developing Nations. Washington, DC: WBI Development Studies, World Bank (2006).

3. Devadasan N, Criel B, Van Damme W, Ranson K, Van der Stuyft P. Indian community health insurance schemes provide partial protection against catastrophic health expenditure. BMC Health Serv Res (2007) 7:43-53. doi:10.1186/1472-6963-7-43

4. McIntyre D, Thiede M, Dahlgren G, Whitehead M. What are the economic consequences for households of illness and of paying for health care in low- and middle-income country contexts? Soc Sci Med (2006) 62:858-65. doi:10.1016/j.socscimed.2005.07.001

5. Savedoff WD, Gottret PE. Governing Mandatory Health Insurance: Learning from Experience. World Bank Publications (2008).

6. Marmor T, Oberlander J, White J. The Obama administration's options for health care cost control: hope versus reality. Ann Intern Med (2009) 150:485-9. doi:10.7326/0003-4819-150-7-200904070-00114

7. Law MR, Kratzer J, Dhalla IA. The increasing inefficiency of private health insurance in Canada. Can Med Assoc J (2014) 186:E470-4. doi:10.1503/ cmaj. 130913

8. Carrin G, Waelkens MP, Criel B. Community-based health insurance in developing countries: a study of its contribution to the performance of health financing systems. Trop Med Int Health (2005) 10:799-811. doi:10.1111/j.1365-3156.2005.01455.x

9. Ekman B. Community-based health insurance in low-income countries: a systematic review of the evidence. Health Policy Plan (2004) 19:249-70. doi:10.1093/heapol/czh031

10. Baeza C, Montenegro F, Núñez M. Extending Social Protection in Health through Community Based Health Organizations: Evidence and Challenges. Geneva International Labor Organization (2002).

11. Alkenbrack S, Lindelow M. The impact of community-based health insurance on utilization and out-of-pocket expenditures in Lao people's democratic republic. Health Econ (2013) 14:379-99. doi:10.1002/hec.3023

12. Mebratie AD, Sparrow R, Yilma Z, Abebaw D, Alemu G, Bedi A. Impact of Ethiopian pilot community-based health insurance scheme on healthcare utilisation: a household panel data analysis. Lancet (2013) 381:S92. doi:10.1016/S0140-6736(13)61346-X suggested the framework for article preparation, review of the manuscript, cross checking of references, and adjustment of article content. MP and DS cross-checked the data and results and reviewed of the manuscript. All authors have read and approved the final manuscript.

\section{ACKNOWLEDGMENTS}

We sincerely thank members of related organizations who contributed their valuable input to this article. The contribution of Margret Storey and Editage for English language checking is much appreciated. Preprint supported the collection of the online comments from general research for necessary modification and advancement.

\section{FUNDING}

This study was supported by GIZ, the Ministry of Health of Nepal, Korea International Co-operation Agency (KOICA) Nepal and the National Research Foundation (NRF-2016S1A5B892520), Korea.

13. Jowett M, Contoyannis P, Vinh ND. The impact of public voluntary health insurance on private health expenditures in Vietnam. Soc Sci Med (2003) 56:333-42. doi:10.1016/S0277-9536(02)00031-X

14. Ogawa S, Hasegawa T, Carrin G, Kawabata K. Scaling up community health insurance: Japan's experience with the 19th century Jyorei scheme. Health Policy Plan (2003) 18:270-8. doi:10.1093/heapol/czg033

15. Wagstaff A, Lindelow M, Jun G, Ling X, Juncheng Q. Extending health insurance to the rural population: an impact evaluation of China's new cooperative medical scheme. J Health Econ (2009) 28:1-19. doi:10.1016/j. jhealeco.2008.10.007

16. Sood N, Bendavid E, Mukherji A, Wagner Z, Nagpal S, Mullen P. Government health insurance for people below poverty line in India: quasi-experimental evaluation of insurance and health outcomes. BMJ (2014) 349:g5114-26. doi:10.1136/bmj.g5114

17. World Bank. Data. (2015). Available from: http://data.worldbank.org/topic/ health

18. Mohanty SK, Agrawal NK, Mahapatra B, Choudhury D, Tuladhar S, Holmgren EV. Multidimensional poverty and catastrophic health spending in the mountainous regions of Myanmar, Nepal and India. Int J Equity Health (2017) 16(1):21-33. doi:10.1186/s12939-016-0514-6

19. Saito E, Gilmour S, Rahman MM, Gautam GS, Shrestha PK, Shibuya K. Catastrophic household expenditure on health in Nepal: a cross-sectional survey. Bull World Health Organ (2014) 92(10):760-7. doi:10.2471/BLT.13. 126615

20. Ghimire R. Community Based Health Insurance Practices in Nepal.(2014). Available from: https://www.academia.edu/5587577/Community_Based_Health_ Insurance_Practices_in_Nepal

21. Pathak AB, Adhikari N. Measuring health outcome and economic cost associated with childhood acute respiratory infections: case of squatter settlements in Kathmandu valley. Econ J Dev Issues (2016) 17(1-2):1-18. doi:10.3126/ejdi. v17i1-2.14518

22. Ranabhat C, Do Y, Ahn D, Lee K, Kim C. Changing pattern of complementary and alternative medicine in Tikapur Nepal: a hope for future health. Altern Integr Med (2014) 3(153):2-6. doi:10.4172/2327-5162.1000153

23. Stoermer M, Fuerst F, Rijal K, Bhandari R, Nogier C, Gautam GS, et al. Review of Community-Based Health Insurance Initiatives in Nepal. Deutsche Gesellschaft fur internationale Zusammenarbeit (GIZ) Gmbh (2012). Available from: http://nhrc.org.np:8080/nhrc/handle/123456789/518

24. Magar A. Envisaging beyond community-based health insurance in Nepal. J Nepal Health Res Counc (2014) 11:1-3. 
25. Jackson SL. Research Methods and Statistics: A Critical Thinking Approach. Boston: Cengage Learning (2015).

26. Meignan D, Knust S, Frayret J-M, Pesant G, Gaud N. A review and taxonomy of interactive optimization methods in operations research. ACM Trans Interact Intell Syst (2015) 5(3):17. doi:10.1145/2808234

27. Greene JC. Mixed Methods in Social Inquiry. USA: John Wiley \& Sons (2007).

28. Driscoll DL, Appiah-Yeboah A, Salib P, Rupert DJ. Merging qualitative and quantitative data in mixed methods research: how to and why not. Ecol Environ Anthropol (2007) 3(1):18-29.

29. Johnson RB, Onwuegbuzie AJ, Turner LA. Toward a definition of mixed methods research. J Mix Methods Res (2007) 1:112-33. doi:10.1177/1558689806298224

30. Creswell JW. Research Design: Qualitative, Quantitative, and Mixed Methods Approaches. United Kingdom: SAGE (2013). 265 p.

31. Lafaille R, Wildeboer H. Validity and Reliability of Observation and Data Collection in Biographical Research. Antwerp, Belgium: International Institute for Advanced Health Studies (1995).

32. Nepal Health Research Council. National Ethical Guidelines for Health Research in Nepal and Standard Operating Procedures. Ranshahpath, Kathmandu, Nepal: Nepal Health Research Coulcil (2011).

33. World Medical Association. World Medical Association Declaration of Helsinki: ethical principles for medical research involving human subjects. JAMA (2013) 310(20):2191-4. doi:10.1001/jama.2013.281053

34. Sato M, Gilson L. Exploring health facilities' experiences in implementing the free health-care policy (FHCP) in Nepal: how did organizational factors influence the implementation of the user-fee abolition policy? Health Policy Plan (2015) 30(10):1272-88. doi:10.1093/heapol/czu136

35. Mebratie A, Sparrow R, Alemu G, Bedi AS. Community-based health insurance schemes. ISS Work Pap Ser Gen Ser (2013) 568:1-47.

36. Panda P, Chakraborty A, Dror DM, Bedi AS. Enrolment in community-based health insurance schemes in rural Bihar and Uttar Pradesh, India. Health Policy Plan (2013) 29:960-74. doi:10.1093/heapol/czt077

37. Levine D, Polimeni R, Ramage I. Insuring Health or Insuring Wealth: Report. (2012). Available from: http://irle.berkeley.edu/files/2014/Insuring-Healthor-Insuring-Wealth.pdf

38. Hamid SA, Roberts J, Mosley P. Can micro health insurance reduce poverty? Evidence from Bangladesh. JRisk Insur (2011) 78:57-82. doi:10.1111/ j.1539-6975.2010.01402.x

39. Gobah FK, Zhang L. The National Health Insurance Scheme in Ghana: prospects and challenges: a cross-sectional evidence. Glob J Health Sci (2011) 3:90. doi:10.5539/gjhs.v3n2p90

40. Kesuma ZM, Chongsuvivatwong V. Utilization of the Local Government Health Insurance Scheme (JKA) for maternal health services among women living in underdeveloped areas of Aceh Province, Indonesia. Asia Pac J Public Health (2014) 27(3):348-59. doi:10.1177/1010539514524818

41. Shimeles A. Community Based Health Insurance Schemes in Africa: The Case of Rwanda. (2010). Report No.: 1403-2465.

42. Philip NE, Kannan S, Sarma SP. Utilization of comprehensive health insurance scheme, Kerala: a comparative study of insured and uninsured below-poverty-line households. Asia Pac J Public Health (2016) 28(1 Suppl):77S-85S. doi:10.1177/1010539515602306

43. Wagstaff A. Health Insurance for the Poor: Initial Impacts of Vietnam's Health Care Fund for the Poor. World Bank Policy Research Working Paper No. 4134 (2007). doi:10.1596/1813-9450-4134

44. Dixon J, Tenkorang EY, Luginaah I. Ghana's National Health Insurance Scheme: a national level investigation of members' perceptions of service provision. BMC Int Health Hum Rights (2013) 13:35-44. doi:10.1186/1472698X-13-35

45. Aggarwal A. Impact evaluation of India's 'Yeshasvini' community-based health insurance programme. Health Econ (2010) 19:5-35. doi:10.1002/hec. 1605

46. Chen G, Yan X. Demand for voluntary basic medical insurance in urban China: panel evidence from the urban resident basic medical insurance scheme. Health Policy Plan (2012) 27:658-68. doi:10.1093/heapol/czs014

47. Franco LM, Diop FP, Burgert CR, Kelley AG, Makinen M, Simpara CHT. Effects of mutual health organizations on use of priority health-care services in urban and rural Mali: a case-control study. Bull World Health Organ (2008) 86:830-8. doi:10.2471/BLT.08.051045

48. Musau S. The Community Health Fund: Assessing Implementation of New Management Procedures in Hanang District Tanzania. (2004). Contract No.: 192294.

49. Gumber A. Hedging the Health of the Poor: The Case for Community Financing in India. (2001). $32 \mathrm{p}$.

50. Gnawali DP, Pokhrel S, Sié A, Sanon M, De Allegri M, Souares A, et al. The effect of community-based health insurance on the utilization of modern health care services: evidence from Burkina Faso. Health Policy (2009) 90:214-22. doi:10.1016/j.healthpol.2008.09.015

51. Jütting JP. Do community-based health insurance schemes improve poor people's access to health care? Evidence from rural Senegal. World Dev (2004) 32:273-88. doi:10.1016/j.worlddev.2003.10.001

52. Michielsen J, Criel B, Devadasan N, Soors W, Wouters E, Meulemans H. Can health insurance improve access to quality care for the Indian poor? Int $J$ Qual Health Care (2011) 23:471-86. doi:10.1093/intqhe/mzr025

53. Angus DE, Manga P, Association CC. Coop-Consumer Sponsored Health Care Delivery Effectiveness: Canadian Cooperative Association. (1990). 77 p.

54. Yan F, Raven J, Wang W, Tolhurst R, Zhu K, Yu B, et al. Management capacity and health insurance: the case of the new cooperative medical scheme in six counties in rural China. Int J Health Plann Manage (2011) 26:357-78. doi:10.1002/hpm.1028

55. MacKay L. Health cooperatives in British Columbia: the unmet potential. B C Med J (2007) 49(3):139-42.

56. Onuoha OC. Cooperative effect and adoption of health care insurance: a study of NHIS in Eastern Nigeria. Scholarly J Bus Adm (2014) 4(5):132-40.

57. Musau SN. Community-Based Health Insurance: Experiences and Lessons Learned from East Africa. (1999). Available from: https://www.popline.org/ node/531507

58. Lee W-Y, Shaw I. The impact of out-of-pocket payments on health care inequity: the case of national health insurance in South Korea. Int J Environ Res Public Health (2014) 11:7304-18. doi:10.3390/ijerph110707304

Conflict of Interest Statement: The authors declare that the research was conducted in the absence of any commercial or financial relationships that could be construed as a potential conflict of interest.

Copyright $\odot 2017$ Ranabhat, Kim, Singh and Park. This is an open-access article distributed under the terms of the Creative Commons Attribution License (CC BY). The use, distribution or reproduction in other forums is permitted, provided the original author(s) or licensor are credited and that the original publication in this journal is cited, in accordance with accepted academic practice. No use, distribution or reproduction is permitted which does not comply with these terms. 